\title{
Organochlorine contaminants in different tissues from Platichthys flesus (Pisces, Pleuronectidea)
}

\author{
Joana Baptista ${ }^{\mathrm{a}, *}$, Pedro Pato ${ }^{\mathrm{b}, \mathrm{c}}$, Armando C. Duarte ${ }^{\mathrm{b}}$, Miguel A. Pardal ${ }^{\mathrm{a}}$ \\ ${ }^{a}$ CFE, Center for Functional Ecology, Department of Life Sciences, University of Coimbra, Apartado 3046, 3001-401 Coimbra, Portugal \\ ${ }^{\mathrm{b}}$ Department of Chemistry \&' Center for Environmental and Marine Studies (CESAM), University of Aveiro, 3810-193 Aveiro, Portugal \\ ' School of Technology and Management, Polytechnic of Viana do Castelo, Avenida do Atlântico, 4900-348 Viana do Castelo, Portugal
}

\section{H I G H L I G H T S}

- Platichthys flesus muscle, liver and gills were analysed for PCBs and HCB.

- P. flesus was analysed along its lifespan, liver presented the highest concentration.

- P. flesus HCB concentration increased in the 3 tissues along the species lifespan.

- P. flesus PCB concentration decreased in the 3 tissues along the species lifespan.

- P. flesus is considered safe for human intake, regarding PCBs and HCB.

\section{A R T I C L E I N F O}

\section{Article history:}

Received 8 November 2012

Received in revised form 9 August 2013

Accepted 12 August 2013

Available online 8 September 2013

\section{Keywords:}

P. flesus

PCBs

$\mathrm{HCB}$

Estuary

Fish market

Condition factor

\begin{abstract}
A B S T R A C T
Polychlorinated biphenyls (PCBs) and hexachlorobenzene (HCB) are organic contaminants that tend to accumulate in fish. Estuaries are exposed to high anthropogenic activities, therefore tending to accumulate more contaminants than the adjacent coastal waters. Platichthys flesus, a fish with high economic value, was analysed for PCBs and HCB along its different age groups, in liver, gills, gonads and muscle. Younger fishes were caught in the estuary, whereas older fishes were caught in the adjacent coastal waters and acquired at Figueira da Foz Regional Office of Docapesca-Portos e Lotas, SA. Both contaminants concentrations follow the pattern: liver $>$ gills $>$ muscle. Hepatosomatic index had the lowest values in younger fishes and the highest values in older fishes. Condition factor values remain stable with age. Younger fishes had higher PCBs concentrations than the older fishes. In opposition HCB was only detected in fish from $3+$ to $5+$ and its concentration tended to increase with age. Overall $P$. flesus is considered safe for human intake.
\end{abstract}

(c) 2013 Elsevier Ltd. All rights reserved.

\section{Introduction}

Organochlorine contaminants are very persistent in the environment. These contaminants tend to accumulate in organisms, due to their lipophilic characteristics, resistance to chemical and metabolic degradation. Human exposure occurs mainly from environmental contamination of food products (Ulbrich and Stahlmann, 2004). Hexachlorobenzene (HCB) was widely used as a fungicide. It was banned globally, due to its persistence in the environment. In the European Union was banned in 1978, in Australia in 1972 and in USA in 1984 (Barber et al., 2005). Nevertheless, HCB is still present in the environment as an unintended by-product in chemical processes, incomplete combustion and an impurity in pesticides (Barber et al., 2005). Polychlorinated biphenyls (PCBs) are synthetic organic chemicals, which tend to

\footnotetext{
* Corresponding author. Tel.: +351 239 836386; fax: +351 239823603.

E-mail address: jbaptista@uc.pt (J. Baptista).
}

accumulate in organisms, due to their lipophilic properties (Eichinger et al., 2010). PCBs were introduced in the environment in the 1920 s, and due to its high persistence in the environment were banned in many countries in 1970s (Bodiguel et al., 2009).

Aquatic ecosystems act as sinks for many organic and inorganic pollutants, resulting from anthropogenic activities. Estuaries are exposed to these activities through urban and industrial development and intensive agriculture (Vasconcelos et al., 2007). Estuaries can accumulate higher quantities of organic contaminants than the adjacent coastal waters, since they can accumulate higher quantities of nutrients and organic material. In general, open coastal habitats are less contaminated, due to their high energy climate and more remote settings (Parnell et al., 2008).

Fish species are very important for the aquatic food webs and human intake. For this reason fishes are widely used to evaluate the aquatic ecosystems health. The European flounder (Platichthys flesus; Pisces, Pleuronectidea) is a demersal fish, with a wide distribution (from Norway to Portugal, Mediterranean, Baltic, North 
White and Black seas) (Morais et al., 2011), being present in both coastal waters and estuarine ecosystems (Vasconcelos et al., 2008). This species is among the most important components of estuarine fish assemblages in temperate latitudes (Franco et al., 2008; Martinho et al., 2010). P. flesus was chosen for this study due to its easy sampling and high ecological and economic relevance. Furthermore, PCBs and HCB exposure to humans occurs mainly by environmental contamination of food products (Ulbrich and Stahlmann, 2004), highlighting the importance of knowing if the consumed fish is appropriated for human intake and if fish size is relevant for risks associated with consumption. P. flesus is a widely studied species regarding PCBs (Goerke and Weber, 2001; Ferreira et al., 2004), but HCB was rarely addressed (Kleinkauf et al., 2004). Regarding PCBs some studies were performed in wild animals (Ferreira et al., 2004), but many studies were performed in laboratory (Grinwis et al., 2000; Goerke and Weber, 2001). Although, no studies of accumulation of these contaminants along the species different age groups were performed so far. The aim of this work was to study the bioaccumulation along the different age groups of PCBs and HCB in P. flesus from the Mondego estuary and adjacent coastal area. $P$. flesus contamination was measure in four different organs, muscle, liver, gonads and gills, along the species different age groups. So, some questions can be posed: Do HCB and PCBs bioaccumulate along the species different age groups?; Are these patterns similar?; Are there differences in the concentration of the different tissues?; Does the contamination present in the Mondego estuary and adjacent coastal waters pose a risk for $P$. flesus general health? Does the intake of $P$. flesus represent a risk for human health?

\section{Materials and methods}

\subsection{Study site}

The Mondego estuary is a small estuary $\left(8.6 \mathrm{~km}^{2}\right)$, located in the western coast of Portugal $\left(40^{\circ} 08^{\prime} \mathrm{N}, 8^{\circ} 50^{\prime} \mathrm{W}\right)$ (Fig. 1). It compromises two arms, the north and the south arm, separated about $7 \mathrm{~km}$ from shore, joining again near the mouth of the estuary. The two arms have distinct hydrological characteristics. The north arm is deeper with $5-10 \mathrm{~m}$ at high tide and 1-3 m tidal range, being dredged frequently to maintain its depth, since is the main navigation channel. The south arm is shallower with 2-4 m depth during high tide and 1-3 m tidal range. The south arm is largely silted up in the upstream areas causing the water to flow mainly through the north arm. The water circulation in the south arm is mainly dependent on tides and on a small freshwater input from the Pranto River, which is controlled by a sluice, according to the water needs of the rice fields of the Mondego agricultural valley.

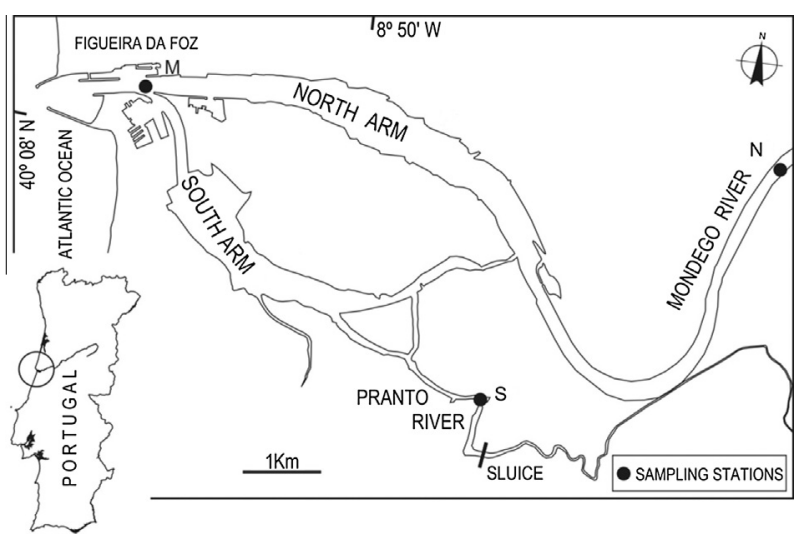

Fig. 1. Mondego estuary sampling sites location.
Table 1

Medium size $(\mathrm{cm})$ and medium weight ( $\mathrm{g}$ ) variation according to age (years), standard deviation between brackets.

\begin{tabular}{lll}
\hline Age (years) & Size $(\mathrm{cm})$ & Weight $(\mathrm{g})$ \\
\hline $0+$ & $12.85(1.50)$ & $20.17(6.27)$ \\
$1+$ & $17.38(1.68)$ & $51.63(5,86)$ \\
$2+$ & $24.01(2.24)$ & $150.35(41.46)$ \\
$3+$ & $27.33(0.55)$ & $226.65(32.05)$ \\
$4+$ & $29.85(1.90)$ & $336.76(103.81)$ \\
$5+$ & $33.53(0.96)$ & $427.63(54.54)$ \\
\hline
\end{tabular}

\subsection{Fish sampling and laboratory work}

$P$. flesus analysed was aged from $0+$ to $5+$ (Table 1$)$, by scale analysis. Younger fishes $(0+$ to $2+)$ were caught in the Mondego estuary, in November and December 2009. Fishing took place during the night and during high tide at 3 sampling stations ( $\mathrm{M}, \mathrm{N}$ and S) (Fig. 1). During the fishing was used a $2 \mathrm{~m}$ beam trawl, with $5 \mathrm{~mm}$ stretched mesh size in the cod end. Each survey consisted of three five-minute hauls at each sampling station. Older fishes (3+ to 5+) were acquired, in February and March 2010, at Figueira da Foz Regional Office of Docapesca-Portos e Lotas, SA, the institution in charge of the first fish sales along the Portuguese mainland.

All fishes were taken into the laboratory, where they were measured $(\mathrm{cm})$, and weighted $(\mathrm{g})$, before collecting the muscles, livers, gonads and gills. Sex was determined by visualization of the gonads, which were only removed from females. Three individual samples from each tissue and age were stored and analysed for PCBs and $\mathrm{HCB}$, given a total of 74 samples analysed. The samples were freeze-dried, homogenized and stored in freezer $\left(-20^{\circ} \mathrm{C}\right)$, until analytical procedure. Due to the lack of mass, in juvenile samples $(0+)$ were used composite samples for analysis, ranging from 3 to 23 individuals depending on the necessary mass.

\section{3. $P C B$ s and $H C B$ analysis}

For the analysis was used $3 \mathrm{~g}$ of muscles, $1 \mathrm{~g}$ of liver, $1.5 \mathrm{~g}$ of gonads and $2 \mathrm{~g}$ of gills. The samples were extracted by sonication (Branson 3510) with a $n$-hexane:acetone (1:1) mixture. The extract was decanted and the process repeated three times. The extract volume was reduced by solvent evaporation using a rotavapor. $10 \%$ of the extract was used for gravimetric determination of lipid content. The remaining $90 \%$ of the sample was reduced by solvent evaporation under a gentle stream of nitrogen. Afterwards a cleanup procedure was performed and lipids present in the remaining sample were removed with sulphuric acid (97\%). Afterwards, the lipid-free extract passed through a multilayered column packed with florisil (Supelclean ${ }^{\circledR}$ Florisil) and anhydrous sodium sulphate, for muscle and gills, and acid silic and florisil (Supelclean ${ }^{\circledR}$ Florisil), for liver, and PCBs and HCB eluted with hexane. Samples were dried, under a gentle stream of nitrogen. A known mixture of PCBs congeners (CB 34, 62, 119, 131 and 173) and HCB-13C were used as internal standards (Ayris et al., 1997), added to the dried extracts, and diluted with iso-octane to a final volume $200 \mu \mathrm{L}$. Samples were analysed on a gas chromatograph equipped with a MDN-12 silica capillary column ( $30 \mathrm{~m} ; 0.25 \mathrm{~mm}$ i.d.; $0.25 \mu \mathrm{m}$ film thickness) coupled to a mass spectrometry detector (GCMS-QP5050A, Shima$\mathrm{dzu}$ ) using electron impact ionization and selected ion monitoring (SIM) acquisition. Helium was employed as the carrier gas, and samples were injected $(1 \mu \mathrm{L})$ in splitless mode with column temperature at $40^{\circ} \mathrm{C}$ and held for $2 \mathrm{~min}$, then programmed to ramp $15^{\circ} \mathrm{C} \mathrm{min}{ }^{-1}$ to $180^{\circ} \mathrm{C}$, and held for $1 \mathrm{~min}, 8^{\circ} \mathrm{C} \mathrm{min}{ }^{-1}$ to $300{ }^{\circ} \mathrm{C}$ and held for $15 \mathrm{~min}$ (injector temperature $=280^{\circ} \mathrm{C}$; interface temperature $=300^{\circ} \mathrm{C}$ ). $\mathrm{HCB}$ content was given in $\mathrm{ng} \mathrm{g}^{-1}$, lipid weight, and the total PCBs content ( $\mathrm{ng} \mathrm{g}^{-1}$, lipid weight) was based on 
the summed concentrations of 6 ecological indicators, considered by the European Union to assess marine pollution ( $\sum_{6 Р С в} 28,52$, $101,138,153$, and 180), and CB 118 ( $\left.\sum_{\mathrm{tPCBs}}\right)$.

For quality assurance and quality control of the HCB and PCBs quantification method, contamination was evaluated by blank controls and results were always below detection limit. The recoveries of the analytical method for the analysed PCB congeners and for HCB were tested by analysis of spike samples and results ranged between $71 \%$ and $106 \%$. Reproducibility was calculated on replicate analysis giving an overall variability of $4-20 \%$. The detection limits for individual PCBs and for HCB ranged between 0.1 and $1.0 \mathrm{ng} \mathrm{g}^{-1}$.

\subsection{Data analysis}

For the $\sum_{\mathrm{tPCBs}}$ concentrations a potential tendency line was performed for each tissue along the species different age groups, obtaining the $R^{2}$ values.

In order to detect differences among the lipid percentage for each tissue a Tukey test (SigmaPlot 11.0) was also performed.

To detect differences in HCB concentration in the different tissues a Kruskal-Wallis one-way analysis of variance on ranks was performed (SigmaPlot 11.0 software). An All Pairwise Multiple Comparison, Dunn's method, was performed to detect differences between each tissue. Log transformation was applied to the data. A linear regression was performed on each tissue to detect different patterns in $\mathrm{HCB}$ concentration along the different age groups.

A one-way ANOVA (SigmaPlot 11.0) was performed in the PCBs congeners for each age in order to detect differences between the different tissues for each congener. No transformation was applied to the data, since all value had a normal distribution.

A decrease in fish general health can affect the normal physiology. Therefore, the Hepatosomatic Index (HSI) was calculated from the liver weight of the fish in relation to its body weight, using the equation:

$\mathrm{HSI}=\frac{\text { Liver Weight }}{\text { Total Body Weight }} * 100$

The condition factor $(\mathrm{CF})$ was calculated from the weight of the fish in relation to its length, and serves as an indicator of growth, nutritional state and energy content of the fish. The CF was calculated using the equation:

$\mathrm{CF}=\frac{\text { Total Body Weight }}{(\text { Body Length })^{3}} * 100$

A 5\% significance level was used for all the analysis.

\section{Results}

\subsection{PCBs concentrations along P. flesus different age groups}

PCBs concentrations were measured along $P$. flesus different age groups. Muscle samples presented the lowest concentrations, ranging from 28 to $553 \mathrm{ng} \mathrm{g}^{-1}$, lipid wt. (Fig. 2), whereas liver presented the highest concentrations ranging from 75 to $5548 \mathrm{ng} \mathrm{g}^{-1}$, lipid wt. (Fig. 2). Gills concentrations ranged from 79 to $587 \mathrm{ng} \mathrm{g}^{-1}$, lipid wt. (Fig. 2). For all tissues PCBs concentrations decreased with age ( $R^{2}=0.95$, for muscle; $R^{2}=0.98$, for liver; $R^{2}=0.99$, for gills) (Fig. 2). Gonads concentration was measured in ages $4+$ and 5+, being $70 \mathrm{ng} \mathrm{g}^{-1}$ and $23 \mathrm{ng} \mathrm{g}^{-1}$, lipid wt., respectively.

Liver presented the highest lipid content, with $16-24 \%$, muscle presented the lowest lipid content, with $0.87-2.8 \%$ (Table 2). Gills tended to increase their lipid content with age, varying from $3.3 \%$ to $14 \%$ (Table 2). Statistical differences were found in the lipid content amongst the 3 tissues $(p<0.001)$.
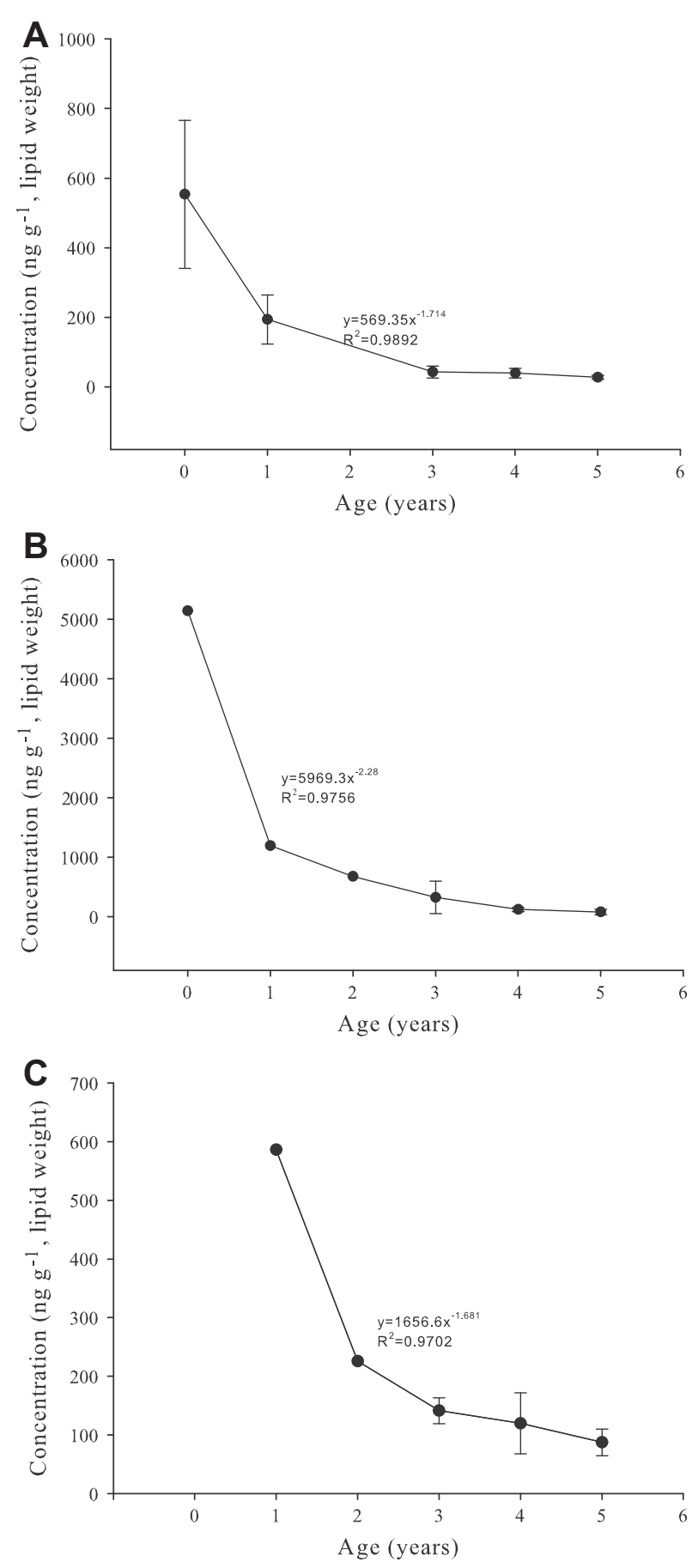

Fig. 2. $\sum_{\mathrm{tPCB}}$ muscle concentration (ng g ${ }^{-1}$, lipid wt.), with standard deviation, in the estuarine and marine environment, for muscle (A), liver (B) and gills (C).

Table 2

Hepatosomatic index, condition factor and lipid (\%), in muscle, liver, gills and gonads according to age.

\begin{tabular}{cllllll}
\hline Age & $\begin{array}{l}\text { Hepatosomatic } \\
\text { index }\end{array}$ & $\begin{array}{l}\text { Condition } \\
\text { factor }\end{array}$ & \multicolumn{3}{l}{ Lipids (\%) } \\
\cline { 4 - 7 } & & 1.18 & 0.87 & 18.16 & & \\
\hline $0+$ & 0.48 & 1.03 & 1.01 & 15.97 & 3.26 & \\
$1+$ & 0.26 & 1.03 & & 20.69 & 8.46 & \\
$2+$ & 0.98 & 1.11 & 2.21 & 19.28 & 9.87 & \\
$3+$ & 1.07 & 1.25 & 2.70 & 19.97 & 11.92 & 1.41 \\
$4+$ & 1.66 & 1.13 & 2.79 & 24.11 & 13.56 & 4.15 \\
$5+$ & 1.54 & & & & & \\
\hline
\end{tabular}


Table 3

HCB concentration (ng g ${ }^{-1}$, lipid wt.) according to age.

\begin{tabular}{llll}
\hline & $3+$ & $4+$ & $5+$ \\
\hline Muscle & 2.16 & 2.75 & 3.43 \\
Gills & 6.22 & 6.45 & 8.42 \\
Liver & 5.90 & 7.96 & 9.13 \\
\hline
\end{tabular}

\subsection{HCB concentration along P. flesus different age groups}

HCB concentration was not detected in juvenile individuals, from the Mondego estuary. On the other hand, HCB concentration was detected in individuals older than 3+, from Figueira da Foz Regional Office of Docapesca-Portos e Lotas, SA (Table 3). The liver presented the highest concentration, whereas the muscle had the lowest (Table 3). HCB concentration tended to increase with age for muscle, liver and gills $\left(R^{2}=0.998 ; R^{2}=0.9753 ; R^{2}=0.829\right.$, respectively).

A Kruskal-Wallis one-way analysis of variance on ranks was performed to detect differences among the three tissues. Dunn's method detected significant differences between liver and muscle, and between gills and muscle (post hoc test, $p<0.05$ ). No significant differences were found between liver and gills (post hoc test, $p>0.05$ ).

\subsection{PCB congeners' pattern}

All PCB congeners tended to decrease their concentration with age (Fig. 3). Less chlorinated congeners presented lower concentration than higher chlorinated congeners, PCB 138 and 153 presented the highest concentration (Fig. 3).

Liver presented higher individual congeners' concentration among the three tissues. The congeners' concentrations in the tissues follow the pattern: liver $>$ gills $>$ muscle.

A one-way ANOVA was performed to detect differences in each tissue for each congener. High chlorinated congeners (PCB 118, 138,153 and 180) presented significant differences between the three tissues, for each age.

\subsection{Physiological conditions of P. flesus along its different age groups}

HSI and the CF can give valuable information about the fish general health, and can be influenced by environmental contaminants. HSI values were measured for each age. Lower values were associated with younger individuals and higher PCBs concentration. Estuarine individuals, ages $0+$ and $1+$, presented lower HSI values than marine individuals, ages $2+$ to $5+$ (Table 2). The CF was measured for each age, and the values did not vary along the species different age groups, ranging from 1.03 to 1.25 (Table 2), and no significant differences were found in the condition factor along the species different age groups $(p=0.564)$.

\section{Discussion}

\subsection{PCBs contaminations along P. flesus different age groups}

Estuaries are sinks for many chemical contaminants due to their proximity to urbanized areas (Gravato et al., 2010). P. flesus is a marine estuarine-dependent species, using estuaries as a nursery ground. Younger individuals, age $0+$, tend to move to the upstream areas, where the salinity values are lower. As they mature (age 1+), they move towards the downstream areas of the estuary. At age 2+, mature individuals move to the adjacent coastal waters, where they will continue their lifecycle. After spawning, P. flesus larvae
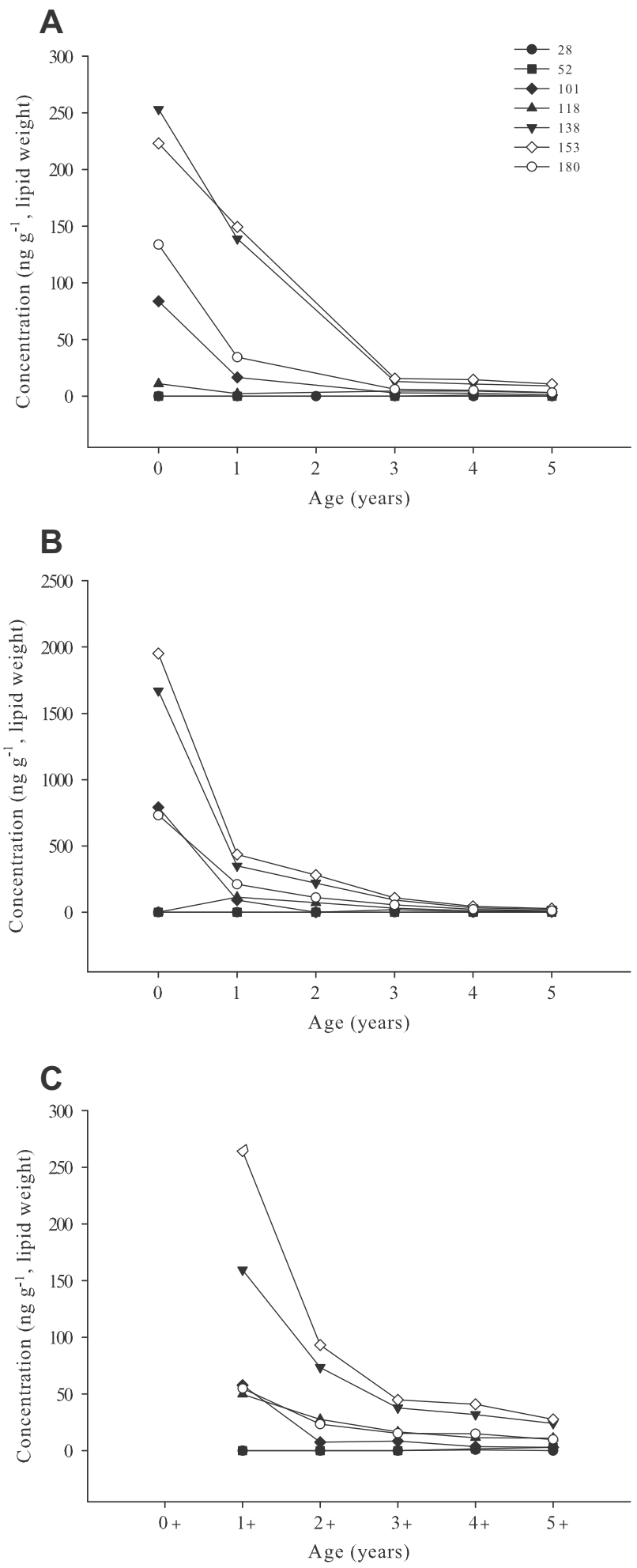

Fig. 3. $\mathrm{PCB}$ congener analysis in the muscle (A), liver (B) and gills (C).

move again to the upstream areas of the estuary, completing the lifecycle (Fig. 4).

Juvenile stages (from the estuarine system) presented higher $\sum$ tPCBs concentration than the mature stages (from the adjacent coastal waters). Class $0+$ presented the highest concentration. This class is located in the most upstream areas of the estuary near the Mondego agricultural valley. Mature fishes presented lower concentration, since the marine environment is less contaminated, 


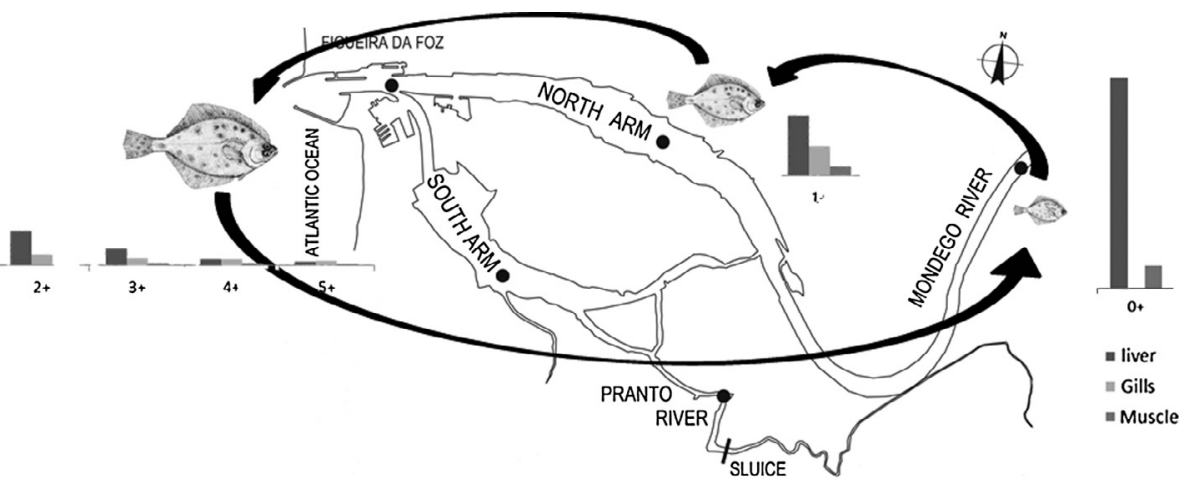

Fig. 4. P. flesus lifecycle in the Mondego estuary and the $\sum_{\mathrm{tPCB}}$ concentration, for liver, gills and muscle.

due to their remote setting (Parnell et al., 2008) (Fig. 4). tPCBs $_{\text {con- }}$ centration decreased with $P$. flesus different age groups. This can also be associated to an increase in metabolic activity and growth dilution (Pastor et al., 1996). Growth dilution can be defined as biomass-specific concentration of pollutants diminishes by accumulation of new biomass (Pickhardt et al., 2002). Growth dilution was observed in other species, such as in the Northern pike (Esox lucius), for mercury contamination (Verta, 1990). The migration pattern of $P$. flesus from a more contaminated to a less contaminated environment and growth dilution may not be the only factors associated to its decontamination.

The high concentration from class $0+$ can be attributed to many factors, such as gonadal pre-contamination, contaminating the recently hatched $P$. flesus. Since, reproduction can be used as a depuration system, also observed in other species, such as largemouth bass (Micropterus salmoides) (Rypel et al., 2007) or sea bass (Dicentrarchus labrax) (Loizeau et al., 2001), furthermore, class 0+ inhabits at the more upstream areas of the estuary near the Mondego rice fields, which can be a possible contamination source of the estuarine system.

Liver presented higher $\sum_{\mathrm{tPCBs}}$ concentration than gills or muscles. The liver is the main organ for PCB storage (Bodiguel et al., 2009), and had higher lipid content. PCBs are very lipophilic and are more prone to accumulate in liver. Nevertheless, gills are associated with higher concentration, as well. Gills can accumulate PCBs by bioconcentration, since they are in direct contact with the surrounding environment (Björk and Gilek, 1997) presenting a large surface area per gram. Moreover, gills are continually transferring organic pollutants from both water and suspended particles into its surface (Yang et al., 2007). Muscle low contamination can be attributed to its low lipid content. Gonads contamination can be attributed to its lipid content and a dislocation of the contamination from the muscle to the gonads. According to Bodiguel et al. (2009), muscle is the major contributor for gonadal contamination.

\section{2. $P C B$ congeners in P. flesus}

PCB congeners' concentration in $P$. flesus decreased with age for all tissues. Congeners can be eliminated by excretion and/or by biotransformation (Eichinger et al., 2010), and are only excreted after they are metabolized (Goerke and Weber, 2001).

The congeners that more contributed to the differences in concentration among the three tissues were the high chlorinated congeners, PCB 118, 138, 153 and 180 . These differences can be explained by the fact that high chlorinated congeners are more slowly degraded metabolically (Wu et al., 2008) and have higher accumulative properties, therefore are more persistent in the environment and in the biological tissues (Bodin et al., 2008).

\subsection{HCB along P. flesus different age groups}

HCB has a long-half life in water and sediment and therefore is extremely persistent in the environment (Barber et al., 2005). HCB can be transported for great distances in the atmosphere before removal, deposition or degradation (Barber et al., 2005).

The muscle presented lower HCB concentration, whereas the liver and gills presented the highest concentration. The liver is the main organ for contaminants storage and presented high lipid content. Gills higher concentration could be due to its larger surface and by the continuously transfer of organic pollutants from both water and suspended particles onto its surface (bioconcentration) (Björk and Gilek, 1997; Yang et al., 2007).

In $P$. flesus different age groups was observed an increase in $\mathrm{HCB}$ concentration. HCB residues were only detected at age class $3+, 4+$ and $5+$. P. flesus from the present study presented lower concentration than P. flesus found in the Baltic Sea (Szlinder-Richert et al., 2008). Estuaries are known to have higher HCB concentration than the adjacent open waters nearby (Barber et al., 2005). So it is possible to assume that generally $P$. flesus contamination was derived from the estuaries rather than the sea. According to Vasconcelos et al. (2008) the Douro estuary (located $80 \mathrm{~km}$ north) had higher contribution (53.3\%) for the fish stock caught in the coastal area of Figueira da Foz, while the Mondego estuary only contributed with $23 \%$. HCB contamination detected in older P. flesus could be due to a contamination already present in fishes from the Douro estuary (Ferreira et al., 2004).

HCB contamination in P. flesus increased along the species different age groups, whereas PCBs concentration decreased. PCBs are metabolized primarily in the liver by the enzyme cytochrome P450 (Ferreira et al., 2004). In fishes this enzyme increases substantially after an exposure to organic contaminants (Collier et al., 1998). Although, this enzyme is important for PCBs detoxification, HCB is not an inductor of cytochrome P450 (Mundy et al., 2012). So, the differences in the contaminants accumulation along $P$. flesus different age groups can be due to differences in detoxification processes. HCB detoxification may not be a process as efficient as PCB detoxification (Ministério da Agricultura, 2012).

\subsection{P. flesus physiological conditions}

HSI and the CF can give valuable information about the fish general health, and are influenced by chemical contamination (Güngördü et al., 2012). A decrease in the general health of $P$. flesus can affect their normal physiology and induce adverse changes. HSI and the CF can give important information on the physiological state of the fish. P. flesus general health can be indicative of their 
reproductive potential and the fitness of their offspring (Kleinkauf et al., 2004).

Regarding HSI, there is some discrepancy in the literature concerning the interpretation of the decrease or increase in HSI values in fish (Güngördü et al., 2012). Some authors pointed out that exposure to pollutants may cause liver dysfunction capable of interfering with normal development, increasing HSI values (Kleinkauf et al., 2004). Though, exposure to PAHs or heavy metals results in a decrease of HSI values (Yang and Baumann, 2006). Accordingly, our results show lower values of HSI with higher concentration of PCBs. But, these results may be interpreted with caution, because multiple factors, other than contaminants, can cause changes in the liver size (Yang and Baumann, 2006). Among these factors can be included sampling season, nutrition or disease (Yang and Baumann, 2006). HCB was only detected in mature individuals, therefore did not interfere in HSI of younger fish. Moreover, despite the opposite tendencies observed in PCBs and HCB the overall concentrations found were low. Accordingly HCB and PCBs contamination at these levels may not be the main influence in HSI values.

Multiple factors can influence the CF, such as food availability, parasites and chemical contamination (Güngördü et al., 2012). In the Mondego estuary and adjacent coastal water the CF is similar at all ages, and it is, also, similar to those found by Kleinkauf et al. (2004), also for P. flesus. The relationship of weight and length remain constant throughout $P$. flesus different age groups, and the condition factor also remains constant along the species different age groups. Therefore, PCBs and HCB contamination, at these levels, does not seem to affect the CF.

\subsection{P. flesus economical value and human intake}

P. flesus is a commercial species, with great economic importance being consumed in many countries such as United Kingdom, France, Spain, Greece or Portugal. P. flesus reproduce in offshore waters and use estuaries as nursery areas or temporary habitats (alternative to coastal areas), because it increases their chances of survival (Martinho et al., 2010). According to FAO fishery statistics, in 2010 around 20000 tons of fish were captured. A higher number than the captured fish in the year 2000, where only 16000 tons (www.fao.org). In Portugal, between the years 2009 and 2010 the estimated captured was 110 and 122.7 tons respectively (www.dgrm.min-agricultura.pt). P. flesus is a high commercial species, so the average prices for $P$. flesus in 2009 and 2010 ranged between 2.96 and $3.10 € \mathrm{~kg}^{-1}$, for the first fish sale. The average price for $P$. flesus for the public sale was around $10 € \mathrm{~kg}^{-1}$, a much higher value than the first fish sale. Figueira da Foz Regional Office of Docapescas-Portos e Lotas, SA provided 10.6 tons of captured fish to the mainland, with an average commercial value of $2.91 € \mathrm{~kg}^{-1}$, for the first fish sale. The Mondego estuary contributed with 2.47 tons (www.dgrm.min-agricultura.pt).

P. flesus is a highly exploited commercial species, but can be particularly vulnerable to chronic and accidental pollution, due their benthic lifestyle and to the fact that nurseries are located in estuarine areas (Eichinger et al., 2010). Recently, the European Union has recommended a tolerance limit of $75 \mathrm{ng} \mathrm{g}^{-1}$ (wet wt.), for fish muscle and fish products, for the sum of the 6 ecological indicators (28, 52, 101, 138, 153 and 180), (Commission Regulation (EU) No. 1259/2011). P. flesus concentration from the fish market is around $0.75 \mathrm{ng} \mathrm{g}^{-1}$ (wet wt.), representing the adult fish. The concentrations of the $P$. flesus from the Mondego estuary are between 1.42 and $0.26 \mathrm{ng} \mathrm{g}^{-1}$ (Table 4). All values are much lower than the one established by the European Union. Therefore, fish from the Figueira da Foz Regional Office of Docapescas-Portos e Lotas, SA, representing the adult fish, and the Mondego estuary, representing the juvenile fish, can be considered safe for human intake, regarding PCBs.
Table 4

PCBs concentration (ng g ${ }^{-1}$, wet wt.) in P. flesus different age groups, standard deviation between brackets.

\begin{tabular}{ll}
\hline Age & Concentration $\left(\mathrm{ng} \mathrm{g}^{-1}\right.$, wet wt. $)$ \\
\hline 1 & $1.42( \pm 0.2)$ \\
2 & $0.84( \pm 0.41)$ \\
3 & \\
4 & $0.84( \pm 0.33)$ \\
5 & $0.85( \pm 0.16)$ \\
6 & $0.62( \pm 0.36)$ \\
\hline
\end{tabular}

Also regarding PCBs, the limit of the daily intake was set in $10 \mathrm{ng} \mathrm{kg}^{-1} \mathrm{bw} \mathrm{d}^{-1}$ (WHO, 2003). The weekly consumed fish for the Portuguese population is around $1250 \mathrm{~g}$ (Lourenço et al., 2006) representing one of the highest consumption rates of fish per capita in the world (www.fao.org). Since the Portuguese average body weight is around $65 \mathrm{~kg}$ and the used concentration was $1.46 \mathrm{ng} \mathrm{g}^{-1}$ (wet wt.) the Portuguese daily intake is around $4 \mathrm{ng} \mathrm{kg}^{-1}$ bw d ${ }^{-1}$, which is lower than the limit set by (WHO, 1997). The values estimated in the present work are lower to the ones estimated in Germany ( $11.2 \mathrm{ng} \mathrm{kg}^{-1} \mathrm{bw} \mathrm{d}^{-1}$ ) (Fromme et al., 2009) and in Italy (11.2 $\mathrm{ng} \mathrm{kg}^{-1} \mathrm{bw} \mathrm{d}^{-1}$ ) (Fattore et al., 2008), and closer the ones estimated in France (5.42 $\mathrm{ng} \mathrm{kg}^{-1} \mathrm{bw} \mathrm{d}^{-1}$ ) (Sirot et al., 2012).

HCB values estimated in the present work (2.2-3.4 $\mathrm{ng} \mathrm{g}^{-1}$, lipid wt.) are lower than those found in previous studies, such as Falandysz et al. (2004), with 6-27 $\mathrm{ng} \mathrm{g}^{-1}$ (lipid wt.) in perch, or by Wang et al. (2010), with 11-37 ng g $^{-1}$ (dry wt.) in carp. Although, no limit was set for HCB intake in fish, the fish daily intake can be considered. The daily intake of HCB by the Portuguese population, with a concentration of $0.09 \mathrm{ng} \mathrm{g}^{-1}$ (wet wt.) is around $0.25 \mathrm{ng} \mathrm{kg}^{-1} \mathrm{bw} \mathrm{d}^{-1}$. According to the US Department of Health and Human Services for non-cancer effects the daily intake limit is $170 \mathrm{ng} \mathrm{kg}^{-1}$ bw d d $^{-1}$ and for neoplastic effects the limit is $160 \mathrm{ng} \mathrm{kg}^{-1}$ bw d ${ }^{-1}$ (WHO, 1997). The daily intake levels regarding HCB of the Portuguese population are lower, than values found in Spain (2.4 $\mathrm{ng} \mathrm{kg}^{-1} \mathrm{bw} \mathrm{d}^{-1}$ ) (Falcó et al., 2004), Finland (24.2 $\mathrm{ng} \mathrm{kg}^{-1}$ bw d ${ }^{-1}$ ) (Moilanen et al., 1986) or Netherlands (14.3 $\mathrm{ng} \mathrm{kg}^{-1} \mathrm{bw} \mathrm{d}^{-1}$ ) (Greve, 1986).

\section{Conclusions}

PCBs and HCB were measure in P. flesus from the Mondego estuary and adjacent coastal waters, along the species different age groups, in liver, gills and muscle. PCBs concentrations decrease along the species different age groups, for all tissues. Liver and gills presented a higher concentration than muscle. HCB residues were not detected in juvenile fishes (estuarine environment), but was detected in the mature fishes (marine environment), with a tendency to increase its concentration along the different age groups. Liver and gills presented higher concentration than muscle.

Human exposure to such contaminants occurs mainly by environmental contamination of food products. Regarding PCBs, the concentration is below the $75 \mathrm{ng} \mathrm{g}^{-1}$ (wet wt.), moreover PCBs daily intake is below the limit establish by (WHO, 1997). Regarding HCB the daily intake is also below the US Department of Health and Human Services tolerance limit. Therefore, P. flesus can be considered safe for human intake.

\section{Acknowledgements}

The authors wish to thank all the colleagues that helped in the field and laboratory work. This work was supported by FCT (Fundação para a Ciência e Tecnologia) through a PhD grant attributed 
to J. Baptista (SFRH/BD/48262/2008), funded by Programa Operacional Potencial Humano of QREN Portugal and by the Portuguese budget through the Ministry of Science Technology and Education. P. Pato acknowledges a postdoctoral fellowship from FCT (SFRH/ $\mathrm{BPD} / 35068 / 2007)$. The authors, also, wish to thank the reviewers for their comments, which helped to improve the manuscript.

\section{References}

Ayris, S., Currado, G.M., Smith, D., Harrad, S., 1997. GC/MS procedures for the determination of PCBs in environmental matrices. Chemosphere 35 (5), 905 917.

Barber, J.L., Sweetman, A., van Wijk, D., Jones, K.C., 2005. Hexachlorobenzene in the global environment: emissions, levels, distribution, trends and processes. Sci. Total Environ. 349, 1-44.

Björk, M., Gilek, M., 1997. Bioaccumulation kinetics of PCB 31, 49 and 153 in the blue mussel, Mytilus edulis L. as a function of algal food concentration. Aquat. Toxicol. 38, 101-123.

Bodiguel, X., Loizeau, V., Le Guellec, A.-M., Roupsard, F., Philippon, X., Mellon-Duval, C., 2009. Influence of sex, maturity, and reproduction on PCB and p, p'DDE concentrations and repartitions in the European hake (Merluccius merluccius, L.) from the Gulf of Lions (N.W. Mediterranean). Sci. Total Environ. 408, 304-311.

Bodin, N., Le Loc'h, F., Caisey, X., Le Guellec, A.-M., Abarnou, A., Loizeau, V., Latrouite, D., 2008. Congener-specific accumulation and trophic transfer of polychlorinated biphenyls in spider crab food webs revealed by stable isotope analysis. Environ. Pollut. 151, 252-261.

Collier, T.K., Anulacion, B.F., Bill, B.D., 1998. Hepatic CYP1A in winter flounder (Pleuronectes americanus) along the Northeast Coast: Results from the National Benthic Surveillance Project. Mar. Pollut. Bull. 37, 86-91.

Eichinger, M., Loizeau, V., Roupsard, F., Le Guellec, A.-M., Bacher, C., 2010. Modelling growth and bioaccumulation of Polychlorinated biphenyls in common sole (Solea solea). J. Sea Res. 64, 373-385.

Falandysz, J., Wyrzykowska, B., Warzocha, J., Barska, I., Garbacik-Wesolowska, A., Szefer, P., 2004. Organochlorine pesticides and PCBs in perch Perca fluviatilis from the Odra/Oder river estuary, Baltic Sea. Food Chem. 87, 17-23.

Falcó, G., Bocio, A., Llobet, J.M., Domingo, J.L., Casas, C., Teixidó, A., 2004. Dietary intake of hexachlorobenzene in Catalonia, Spain. Sci. Total Environ. 322, 63-70.

Fattore, E., Fanelli, R., Dellatte, E., Turrini, A., di Domenico, A., 2008. Assessment of the dietary exposure to non-dioxin-like PCBs of the Italian general population. Chemosphere 73, S278-S283.

Ferreira, M., Antunes, P., Gil, O., Vale, C., Reis-Henriques, M.A., 2004. Organochlorine contaminants in flounder (Platichthys flesus) and mullet (Mugil cephalus) from Douro estuary, and their use as sentinel species for environmental monitoring. Aquat. Toxicol. 69, 347-357.

Franco, A., Elliot, M., Franzoi, P., Torricelli, P., 2008. Life strategies of fishes in European estuaries: the functional guild approach. Mar. Ecol.-Prog. Ser. 354, 219-228.

Fromme, H., Shahin, N., Boehmer, S., Albrecht, M., Parlar, H., Liebl, B., Mayer, R., Bolte, G., 2009. Dietary intake of non-dioxin-like polychlorinated biphenyls $(\mathrm{PCB})$ in Bavaria, Germany. Results from the Integrated Exposure Assessment Survey (INES). Gesundheitswesen 71, 275-280.

Goerke, H., Weber, K., 2001. Species-specific elimination of polychlorinated biphenyls in estuarine animals and its impact on residue patterns. Mar. Environ. Res. 51, 131-149.

Gravato, C., Guimarães, L., Santos, J., Faria, M., Alves, A., Guilhermino, L., 2010. Comparative study about the effects of pollution on glass and yellow eels (Anguilla anguilla) from the estuaries of Minho, Lima and Douro Rivers (NW Portugal). Ecotoxicol. Environ. Saf. 73, 524-533.

Greve, P.A., 1986. Environmental and human exposure to hexachlorobenzene in the Netherlands, vol. 77IARC Sci Publ, pp. 87-97.

Grinwis, G.C.M., Vethaak, A.D., Wester, P.W., Vos, J.G., 2000. Toxicology of environmental chemicals in the flounder (Platichthys flesus) with emphasis on the immune system: field, semi-field (mesocosm) and laboratory studies. Toxicol. Lett. 112-113, 289-301.

Güngördü, A., Erkmen, B., Kolankaya, D., 2012. Evaluation of spatial and temporal changes in biomarker responses in the common carp (Cyprinus carpio L.) for biomonitoring the Meriç Delta, Turkey. Environ. Toxicol. Pharmacol. 33, 431439 .

Kleinkauf, A., Connor, L., Swarbreck, D., Levene, C., Walker, P., Johnson, P.J., Leah, R.T. 2004. General conditions biomarkers in relation to contaminated burden in European flounder (Platichthys flesus). Ecotoxicol. Environ. Saf. 58, 335-355.
Loizeau, V., Abarnou, A., Cugier, P., Jaouen-Madoulet, A., Le Guellec, A.-M. Menesguen, A., 2001. A model of PCB bioaccumulation in the sea bass food web from the Seine Estuary (Eastern English Channel). Mar. Pollut. Bull. 43, $242-255$.

Lourenço, H.M., Afonso, C., Gonçalves, S., Martins, M.F., Batista, I., Nunes, M.L., 2006. Heavy metals in fishing products and aquaculture. In: Livro de Resumos das II Jornadas "Qualidade, Inovação e Segurança dos Productos das Pesca". INIAP/ IPIMAR/DITVPP eds, Lisboa, Portugal, pp. 14.

Martinho, F., Dolbeth, M., Viegas, I., Baptista, J., Cabral, H.N., Pardal, M.A., 2010. Does the flat fish community of the Mondego estuary (Portugal) reflect environmental changes? J. Appl. Ichthyol. 26, 843-852.

Ministério da Agricultura. <http://www.dgrm.min-agricultura.pt> (accessed 11.09.12).

Moilanen, R., Pyysalo, H., Kumpulainen, J., 1986. Average total dietary intakes of organochlorine compounds from the Finish diet. Z Lebensm Unters Forsch 182, 484-488.

Morais, P., Dias, E., Babaluk, J., Antunes, C., 2011. The migration patterns of the European flounder Plathichthys flesus (Linnaeus, 1758) (Pleuronectidae, Pisces) at the southern limit of its distribution range: ecological implications and fishery management. J. Sea Res. 65, 235-246.

Mundy, L.J., Crump, D., Jones, S.P., Konstantinov, A., Utley, F., Potter, D., Kennedy, S.W., 2012. Induction of cytochrome P4501A by highly purified hexachlorobenzene in primary cultures of ring-necked pheasant and Japanese quail embryo hepatocytes. Comp. Biochem. Physiol., Part C: Toxicol. Pharmacol. C155, 498-505.

Parnell, P.E., Groce, A.K., Stebbins, T.D., Dayton, P.K., 2008. Discriminations sources of PCB contamination in fish on the coastal shelf of San Diego, California (USA). Mar. Pollut. Bull. 56, 1992-2002.

Pastor, D., Boix, J., Fernández, V., Albaigés, J., 1996. Bioaccumulation of organochlorinated contaminants in three estuarine fish species (Mullus barbatus, Mugil cephalus and Dicentrarcus labrax). Mar. Pollut. Bull. 32, 257-262.

Pickhardt, P.C., Folt, C.L., Chen, C.Y., Klaue, B., Blum, J.D., 2002. Algal blooms reduce the uptake of toxic methylmercury in fresh food webs. Proc. Natl. Acad. Sci. USA 99, 4419-4423.

Rypel, A.L., Findlay, R.H., Mitchell, J.B., Bayne, D.R., 2007. Variations in PCB concentrations between genders of six warmwater fish species in Lake Logan Martin, Alabama, USA. Chemosphere 68, 1707-1715.

Sirot, V., Tard, A., Venisseau, A., Brosseaud, A., Marchand, P., Le Bizec, B., Leblanc, J.C, 2012. Dietary ecposure to polychlorinated dibenzo-o-p-dioxins, polychlorinated dibenzofurans and polychlorinated bephenyls of the French population: Results of the second French total diet study. Chemosphere 88, $492-500$

Szlinder-Richert, J., Barska, I., Mazerski, J., Usydus, Z., 2008. Organochlorine pesticides in fish from the southern Baltic Sea: Levels, bioaccumulation features and temporal trends during the 1995-2006 period. Mar. Pollut. Bull. 56, 927-940.

Ulbrich, B., Stahlmann, R., 2004. Development toxicity of polychlorinated biphenyls (PCBs): a systematic review of experimental data. Arch. Toxicol. 78, 252-268.

Vasconcelos, R.P., Reis-Santos, P., Fonseca, V., Maia, A., Ruano, M., França, S., Vinagre C., Costa, M.J., Cabral, H., 2007. Assessing anthropogenic pressures on estuarine fish nurseries along the Portuguese coast: a multi-metric index and conceptual approach. Sci. Total Environ. 374, 199-215.

Vasconcelos, R.P., Reis-Santos, P., Tanner, S., Maia, A., Latkoczy, C., Günther, D. Costa, M.J., Cabral, H., 2008. Evidence of estuarine nursery origin of five coastal fish species along the Portuguese coast through otolith elemental fingerprints. Estuar. Coast. Shelf Sci. 79, 317-327.

Verta, M., 1990. Changes in fish mercury concentrations in an intensively fished lake. Can. J. Fish Aquat. Sci. 47 (10), 1888-1897.

Wang, G., Lu, Y., Han, J., Luo, W., Shi, Y., Wang, T., Sun, Y., ng et al. 2010 Hexachlorobenzene sources, levels and human exposure in the environment of China. Environ. Int. 36, 122-130.

WHO, 1997. <www.who.org.int> (accessed 18.09.12).

WHO, 2003. <http://www.who.int> (accessed 18.09.12).

Wu, J.-P., Luo, X.-J., Zang, Y., Luo, Y., Chen, S.-J., Mai, B.-X., Yang, Z.-Y., 2008 Bioaccumulation of polybrominated diphenyl ethers (PBDEs) and polychlorinated biphenyls (PCBs) in wild aquatic species from an electronic waste (e-waste) recycling site in South China. Environ. Int. 34, 1109-1113.

Yang, X., Baumann, P.C., 2006. Biliary PAH metabolites and hepatosomatic index of brown bullheads from Lake Erie tributaries. Ecol. Indic. 6, 567-574.

Yang, R., Yao, T., Xu, B., Jiang, G., Xin, X., 2007. Accumulation features of organochlorine pesticides and heavy metals in fish from high mountain lakes and Lhasa River in the Tibetan Plateau. Environ. Int. 33, 151-156. 